\title{
Coiled-Coil Alpha-Helical Rod Protein 1
}

National Cancer Institute

\section{Source}

National Cancer Institute. Coiled-Coil Alpha-Helical Rod Protein 1. NCI Thesaurus. Code C99625.

Coiled-coil alpha-helical rod protein 1 (782 aa, $\sim 89 \mathrm{kDa}$ ) is encoded by the human CCHCR1 gene. This protein may be involved in the proliferation and differentiation of keratinocytes. 